Bull. Chem. Soc. Ethiop. 2013, 27(2), 213-220.

Printed in Ethiopia

DOI: http://dx.doi.org/10.4314/bcse.v27i2.6

ISSN 1011-3924

(c) 2013 Chemical Society of Ethiopia

\title{
SYNTHESIS, CHARACTERIZATION AND ANTIBACTERIAL ACTIVITY OF 2-p-TOLYL-1H-IMIDAZO[4,5-f][1,10]PHENANTHROLINE AND ITS Co(II), Ni(II) AND Cu(II) COMPLEXES
}

\author{
Mesut Gomleksiz ${ }^{1 *}$, Cihan Alkan ${ }^{2}$ and Belgin Erdem ${ }^{3}$ \\ ${ }^{1}$ Ahi Evran University, Faculty of Science and Arts, Department of Chemistry, TR-40100, \\ Kirsehir, Turkey \\ ${ }^{2}$ Firat University, Faculty of Science and Arts, Department of Chemistry, TR-23119, Elazig, \\ Turkey \\ ${ }^{3}$ Ahi Evran University, Faculty of Science and Arts, Department of Biology, TR-40100, \\ Kirsehir, Turkey
}

(Received November 9, 2011; revised March 26, 2013)

\begin{abstract}
In this study, the ligand, 2-p-tolyl-1H-imidazo[4,5-f][1,10]phenanthroline (L) was synthesized by the reaction of 1,10-phenanthroline-5,6-dione with 4-methylbenzaldehyde. The complexes of $\mathrm{L}$ were prepared with $\mathrm{Co}$ (II), $\mathrm{Ni}$ (II) and $\mathrm{Cu}$ (II) chlorides. The ligand and its complexes were characterized by IR, UV/VIS, ${ }^{1} \mathrm{H}$ NMR, TGA, elemental analyses, molar conductivity and magnetic susceptibility. The complexes were proposed to be distorted octahedral geometry. Antibacterial activity of the ligand and its complexes were tested against selected bacteria. The minimum inhibitory concentration (MIC) was determined for the ligand and its complexes.
\end{abstract}

KEY WORDS: 1,10-Phenanthroline, Imidazole, Cobalt complex, Nickel complex, Copper complex, Antibacterial activity

\section{INTRODUCTION}

Metal complexes containing diimine ligands such as 1,10-phenanthroline and its derivatives have gained importance because of their versatile roles as building blocks for the synthesis of metallo-dendrimers and as molecular scaffolding for supramolecular assemblies, and in analytical chemistry, catalysis, electrochemistry, ring-opening metathesis polymerization and biochemistry [1-10].

1,10-Phenanthroline has a rigid framework and possesses a superb ability to coordinate many metal ions, which show potential for technological applications, due to their strong absorption in the ultraviolet spectral region, bright light-emission and good electro- and photoactive properties [11-14]. The photochemical and redox properties of complexes can be varied systematically through appropriate substitution on the phenanthroline rings [15-17]. 1,10Phenanthroline, as well as some of its derived complexes, do exhibit antimicrobial properties $[18,19]$.

We report here the synthesis and characterization of new $\mathrm{Co}(\mathrm{II}), \mathrm{Ni}(\mathrm{II})$ and $\mathrm{Cu}$ (II) complexes with 1,10-Phenanthroline imidazole derivative, which is 2-p-tolyl-1H-imidazo[4,5-f][1,10] phenanthroline (L). These compounds were screened for antibacterial activity against these bacterial strains; A. hydrophila, S. aureus, K. pneumoniae, P. aeruginosa, S. marcescens, E. aerogenes, B. subtilis, E. coli and E. faecalis.

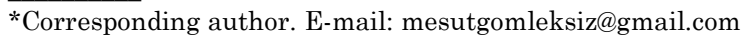




\section{EXPERIMENTAL}

\section{Materials and physical measurements}

1,10-Phenanthroline-5,6-dione was synthesized according to a published method [20]. Ethanol was dried over anhydrous copper(II) sulfate and distilled over metallic sodium. All other chemicals were of analytical grade and were used as purchased.

Elemental analyses (C, H, N) were performed by using a Leco 932 elemental analyzer (Inonu University, Malatya, Turkey). ${ }^{1} \mathrm{H}$ NMR spectra were recorded on a Bruker $300 \mathrm{MHz}$ spectrometer (Inonu University, Malatya, Turkey) in DMSO- $\mathrm{d}_{6}$. The IR spectra were obtained using $\mathrm{KBr}$ discs on a Ati Unicam Mattson 1000 Series FT-IR spectrophotometer (Firat University, Elazig, Turkey). The electronic absorption spectra in the $200-1100 \mathrm{~nm}$ range were obtained in DMF on a Shimadzu UV-1700 UV-Visible spectrophotometer (Firat University, Elazig, Turkey). Magnetic susceptibility were measured at room temperature with MK-1 model Gouy balance (Firat University, Elazig, Turkey) using $\mathrm{Hg}\left[\mathrm{Co}(\mathrm{SCN})_{4}\right]$ as a reference for calibrant. Conductivities of a $10^{-3} \mathrm{M}$ solution of the complexes were measured in DMF at $25^{\circ} \mathrm{C}$ using a CMD 750 WPA model conductivity meter (Firat University, Elazig, Turkey). Thermogravimetric analyses (TGA) were carried out by Shimadzu-50 thermal analyzer (Firat University, Elazig, Turkey) in a dynamic nitrogen atmosphere in the $20-600{ }^{\circ} \mathrm{C}$ and a heating rate $20{ }^{\circ} \mathrm{C} \mathrm{min}^{-1}$.

\section{Antibacterial activity}

The in vitro antibacterial screening effects of the compounds were tested against nine bacterial strains namely A. hydrophila (ATCC 7966), S. aureus (ATCC 29213), K. pneumoniae (ATCC 21541), P. aeruginosa (ATCC 27853), S. marcescens (ATCC 21074), E. aerogenes (ATCC 5402), B. subtilis (ATCC 6633), E. coli (ATCC 25922) and E. faecalis (ATCC 29212).

All bacteria were inoculated into Nutrient Broth (Difco) and incubated for $24 \mathrm{~h}$. In the agar well diffusion method (Mueller Hinton Agar (Oxoid) for bacteria), the dilution plate method was used to enumerate microorganisms $\left(10^{5}\right.$ bacteria per $\left.\mathrm{mL}\right)$ for $24 \mathrm{~h}[21,22,23]$. By using a sterilised cork borer (7 $\mathrm{mm}$ diameter), wells were dug in the culture plates. Compounds dissolved in DMF $(1000 \mu \mathrm{g} / \mathrm{mL})$ were added $(75 \mu \mathrm{L})$ to these wells. The petri dishes were left at $4{ }^{\circ} \mathrm{C}$ for $2 \mathrm{~h}$ and then the plates were incubated at $37{ }^{\circ} \mathrm{C}$ for bacteria $(18-24 \mathrm{~h})$. At the end of the period, inhibition zones formed on the medium were evaluated is milimeters ( $\mathrm{mm})$. DMF was used as a negative control under similar conditions for comparison. Ampicillin (AMP) was used as the reference drug in positive control. All the experiments were repeated three times and the average values are presented.

The minimum inhibitory concentration (MIC) was determined by broth microdilution method [21]. For MIC determination, suspensions of microorganism (0.5 McFarland), MullerHinton broth, solutions of the substances to be tested $(1000 \mu \mathrm{g} / \mathrm{mL}$ in DMF). An equal volume of bacterial inoculum was added to each well on the microtitre plate. In this manner final concentration of compounds range 1000-3.91 $\mu \mathrm{g} / \mathrm{mL}$ in twofold dilution step. The inoculated plates were then incubated at $37^{\circ} \mathrm{C}$ for $18-24 \mathrm{~h}$.

\section{Synthesis of ligand $(L)$}

The ligand (L) (Figure 1) was synthesized by a method similar to the one described previously $[24,25]$. A mixture of 1,10-phenanthroline-5,6-dione $(0.4 \mathrm{~g}, 2 \mathrm{mmol})$, ammonium acetate (3.1 $\mathrm{g}, 40 \mathrm{mmol})$, 4-methylbenzaldehyde $(0.27 \mathrm{~g}, 2.3 \mathrm{mmol})$ and glacial acetic acid $(30 \mathrm{~mL})$ was refluxed for $2 \mathrm{~h}$, then cooled to room temperature and diluted with water $(60 \mathrm{~mL})$. Dropwise 
2-p-Tolyl-1h-imidazo[4,5-f][1,10]phenanthroline and its $\mathrm{Co}(\mathrm{II}), \mathrm{Ni}(\mathrm{II})$ and $\mathrm{Cu}(\mathrm{II})$ complexes 215

addition of concentrated aqueous ammonia gave yellow precipitate, which was collected and washed with water. The crude product dissolved in ethanol was purified by filtration on silica gel. The principal yellow band was collected. Evaporation of the solution gave yellow crystals. It was filtered, washed with ethanol and recrystallized from ethanol then dried at $80{ }^{\circ} \mathrm{C}$. Yield $0.384 \mathrm{~g}(62 \%) .{ }^{1} \mathrm{H}$ NMR (300 MHz, DMSO-d $\left.{ }_{6}, \delta \mathrm{ppm}\right): 13.69$ (s, 1H, NH), 9.05-9.01 (dd, 2H, $\left.\mathrm{C}_{\mathrm{Ar}}-\mathrm{H}\right), 8.95-8.89\left(\mathrm{dd}, 2 \mathrm{H}, \mathrm{C}_{\mathrm{Ar}}-\mathrm{H}\right), 8.21-8.16\left(\mathrm{~d}, 2 \mathrm{H}, \mathrm{C}_{\mathrm{Ar}}-\mathrm{H}\right), 7.87-7.80\left(\mathrm{~m}, 2 \mathrm{H}, \mathrm{C}_{\mathrm{Ar}}-\mathrm{H}\right), 7.45-$ $7.39\left(\mathrm{~d}, 2 \mathrm{H}, \mathrm{C}_{\mathrm{Ar}}-\mathrm{H}\right), 2.41\left(\mathrm{~s}, 3 \mathrm{H}, \mathrm{CH}_{3}\right)$.

Synthesis of complexes

[Co $\left.(\mathrm{L})_{2} \mathrm{Cl}_{2}\right] \cdot \mathrm{H}_{2} \mathrm{O}$. A ethanolic $(10 \mathrm{~mL})$ solution of the $\mathrm{CoCl}_{2} \cdot 6 \mathrm{H}_{2} \mathrm{O}(0.075 \mathrm{mmol}, 0.019 \mathrm{~g})$ was added a hot solution of the $\mathrm{L}(0.047 \mathrm{~g}, 0.15 \mathrm{mmol})$ in ethanol $(10 \mathrm{~mL})$. The reaction mixture was refluxed for $24 \mathrm{~h}$. The mixture was cooled to room temperature, the resulting orange solid was filtered, washed with ethanol and recrystallized in ethanol. The product was dried at $80{ }^{\circ} \mathrm{C}$ in a vacuum oven. Yield: $0.032 \mathrm{~g}(56 \%)$.

[Ni( $\left.\mathrm{L}_{2} \mathrm{Cl}_{2}\right] .2 \mathrm{H}_{2} \mathrm{O}$. A ethanolic $(10 \mathrm{~mL})$ solution of the $\mathrm{NiCl}_{2} \cdot 6 \mathrm{H}_{2} \mathrm{O}(0.075 \mathrm{mmol}, 0.018 \mathrm{~g})$ was added a hot solution of the $\mathrm{L}(0.047 \mathrm{~g}, 0.15 \mathrm{mmol})$ in ethanol $(10 \mathrm{~mL})$. The reaction mixture was refluxed for $26 \mathrm{~h}$. The mixture was cooled to room temperature, the resulting orange solid was filtered, washed with ethanol and recrystallized in ethanol. The product was dried at $80{ }^{\circ} \mathrm{C}$ in a vacuum oven. Yield: $0.038 \mathrm{~g}(65 \%)$.

$\left[\mathrm{Cu}\left(\mathrm{L}_{2} \mathrm{Cl}_{2}\right] \cdot 2 \mathrm{H}_{2} \mathrm{O}\right.$. A ethanolic $(10 \mathrm{~mL})$ solution of the $\mathrm{CuCl}_{2} \cdot \mathrm{H}_{2} \mathrm{O}(0.075 \mathrm{mmol}, 0.013 \mathrm{~g})$ was added a hot solution of the $\mathrm{L}(0.047 \mathrm{~g}, 0.15 \mathrm{mmol})$ in ethanol $(10 \mathrm{~mL})$. The reaction mixture was refluxed for $20 \mathrm{~h}$. The mixture was cooled to room temperature, the resulting green solid was filtered, washed with ethanol and recrystallized in ethanol. The product was dried at $80{ }^{\circ} \mathrm{C}$ in a vacuum oven. Yield: $0.028 \mathrm{~g}(48 \%)$.

\section{RESULTS AND DISCUSSION}

Elemental analyses indicate that the metal:ligand ratio are 1:2 in all the complexes (Table 1, Figure 2). The ligand (L) and its complexes are soluble in EtOH, DMF and DMSO.

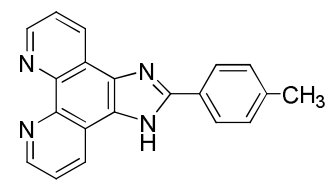

Figure 1. Structure of the ligand (L).

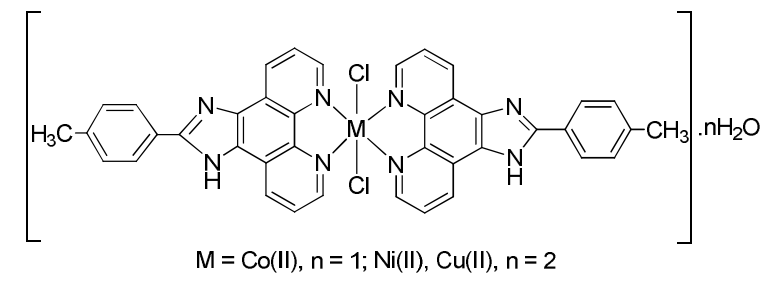

Figure 2. Structure of the $\left[\mathrm{Co}(\mathrm{L})_{2} \mathrm{Cl}_{2}\right] \cdot \mathrm{H}_{2} \mathrm{O},\left[\mathrm{Ni}(\mathrm{L})_{2} \mathrm{Cl}_{2}\right] \cdot 2 \mathrm{H}_{2} \mathrm{O}$ and $\left[\mathrm{Cu}(\mathrm{L})_{2} \mathrm{Cl}_{2}\right] \cdot 2 \mathrm{H}_{2} \mathrm{O}$ complexes.

Bull. Chem. Soc. Ethiop. 2013, 27(2) 
IR spectra

In the IR spectra (Table 2) of $\left[\mathrm{Co}(\mathrm{L})_{2} \mathrm{Cl}_{2}\right] \cdot \mathrm{H}_{2} \mathrm{O},\left[\mathrm{Ni}(\mathrm{L})_{2} \mathrm{Cl}_{2}\right] \cdot 2 \mathrm{H}_{2} \mathrm{O}$ and $\left[\mathrm{Cu}(\mathrm{L})_{2} \mathrm{Cl}_{2}\right] \cdot 2 \mathrm{H}_{2} \mathrm{O}$, the bands were observed at the 3420,3417 and $3428 \mathrm{~cm}^{-1}$ as broad bands, respectively, are due to $\mathrm{OH}$ stretching vibrations of $\mathrm{H}_{2} \mathrm{O}$ molecules [26-28]. The presence of $\mathrm{H}_{2} \mathrm{O}$ is also confirmed by TGA analyses.

The presence of broad bands in the IR spectra of the ligand and its complexes in the 3038$3150 \mathrm{~cm}^{-1}$ range may be assigned to the $\mathrm{N}-\mathrm{H}$ stretching vibrations. This is indicating hydrogenbonding between the molecules [29, 30].

The stretching vibration at $1604 \mathrm{~cm}^{-1}$ of the $\mathrm{C}=\mathrm{N}$ (imidazole ring) group of the ligand not affected in its complexes, indicating that the nitrogen atom of this group is not involved in coordination for all the complexes. On the other hand, the bands observed in the 1503-1561 $\mathrm{cm}^{-1}$ range of the $\mathrm{C}=\mathrm{N}$ (phenanthroline ring) and $\mathrm{C}=\mathrm{C}$ (Ar) groups were shifted to higher frequencies in the range $1522-1577 \mathrm{~cm}^{-1}$ in all the complexes of the ligand, that indicates the participation nitrogen atom of the $\mathrm{C}=\mathrm{N}$ (phenanthroline ring) groups in coordination of the metal ion [31, 32].

The bands of the N-H and $\operatorname{Ar}(\mathrm{C}-\mathrm{H})$ groups in all the complexes of the ligand shifted to negative frequencies after complexations. The negative frequency shifts of these groups may be attributed to flow of electrons from these groups to the phenanthroline ring due to electron flow from the nitrogen atom of the phenanthroline ring to the metal ion after complexations.

Table 1. Some analytical data and physical properties of the ligand and its complexes.

\begin{tabular}{|c|c|c|c|c|c|c|c|c|}
\hline \multirow[t]{2}{*}{ Compound } & \multirow[t]{2}{*}{$\begin{array}{c}\text { Yield, } \\
\%\end{array}$} & \multirow[t]{2}{*}{ Color } & \multirow[t]{2}{*}{ Molecular formula } & \multirow{2}{*}{$\begin{array}{l}\mathrm{FW}, \\
\mathrm{g} / \mathrm{mol}\end{array}$} & \multicolumn{3}{|c|}{$\begin{array}{c}\text { Elemental analyses } \\
\text { calculated (found), \% }\end{array}$} & \multirow{2}{*}{$\begin{array}{c}\Lambda_{\mathrm{M}}\left(\Omega^{-1}\right) \\
\left.\mathrm{cm}^{2} \cdot \mathrm{mol}^{-1}\right)\end{array}$} \\
\hline & & & & & $\mathrm{C}$ & $\mathrm{H}$ & $\mathrm{N}$ & \\
\hline $\mathrm{L}$ & 62 & Yellow & $\mathrm{C}_{20} \mathrm{H}_{14} \mathrm{~N}_{4}$ & 310.35 & - & - & - & - \\
\hline$\left[\mathrm{Co}(\mathrm{L})_{2} \mathrm{Cl}_{2}\right] \cdot \mathrm{H}_{2} \mathrm{O}$ & 56 & Orange & $\mathrm{C}_{40} \mathrm{H}_{30} \mathrm{~N}_{8} \mathrm{OCl}_{2} \mathrm{Co}$ & 768.56 & $\begin{array}{c}62.51 \\
(61.96) \\
\end{array}$ & $\begin{array}{c}3.93 \\
(3.50) \\
\end{array}$ & \begin{tabular}{|c|}
14.58 \\
$(15.03)$
\end{tabular} & 11.47 \\
\hline$\left[\mathrm{Ni}(\mathrm{L})_{2} \mathrm{Cl}_{2}\right] \cdot 2 \mathrm{H}_{2} \mathrm{O}$ & 65 & Orange & $\mathrm{C}_{40} \mathrm{H}_{32} \mathrm{~N}_{8} \mathrm{O}_{2} \mathrm{Cl}_{2} \mathrm{Ni}$ & 786.33 & $\begin{array}{c}61.10 \\
(60.47) \\
\end{array}$ & $\begin{array}{c}4.10 \\
(4.68) \\
\end{array}$ & \begin{tabular}{|c|}
14.25 \\
$(13.77)$ \\
\end{tabular} & 9.46 \\
\hline$\left[\mathrm{Cu}(\mathrm{L})_{2} \mathrm{Cl}_{2}\right] \cdot 2 \mathrm{H}_{2} \mathrm{O}$ & 48 & Green & $\mathrm{C}_{40} \mathrm{H}_{32} \mathrm{~N}_{8} \mathrm{O}_{2} \mathrm{Cl}_{2} \mathrm{Cu}$ & 791.19 & $\begin{array}{c}60.72 \\
(60.20)\end{array}$ & $\begin{array}{c}4.08 \\
(4.03)\end{array}$ & \begin{tabular}{|c|}
14.16 \\
$(13.58)$ \\
\end{tabular} & 10.32 \\
\hline
\end{tabular}

Table 2. Significant bands in the IR spectra $\left(\mathrm{cm}^{-1}\right)$ of the ligand and its complexes.

\begin{tabular}{|c|c|c|c|c|c|c|}
\hline Compounds & $\begin{array}{c}(\mathrm{O}-\mathrm{H})_{\text {str. }} \\
\mathrm{H}_{2} \mathrm{O}\end{array}$ & $(\mathrm{N}-\mathrm{H})_{\text {str. }}$ & $\mathrm{Ar}(\mathrm{C}-\mathrm{H})_{\text {str. }}$ & $\mathrm{Al}(\mathrm{C}-\mathrm{H})_{\text {str. }}$ & $\begin{array}{c}(\mathrm{C}=\mathrm{N})_{\text {str. }} \\
\text { imidazole ring }\end{array}$ & $\begin{array}{c}\text { Ar }(\mathrm{C}=\mathrm{C})_{\text {str. }} \text { and } \\
\text { phen ring }(\mathrm{C}=\mathrm{N})_{\text {str. }}\end{array}$ \\
\hline $\mathrm{L}$ & - & $3150(\mathrm{br})$ & 3010 & 2851,2912 & 1604 & $1561,1519,1503$ \\
\hline$\left[\mathrm{Co}(\mathrm{L})_{2} \mathrm{Cl}_{2}\right] \cdot \mathrm{H}_{2} \mathrm{O}$ & $3420(\mathrm{br})$ & $3038(\mathrm{br})$ & 2978 & 2851,2917 & 1604 & $1574,1550,1522$ \\
\hline$\left[\mathrm{Ni}(\mathrm{L})_{2} \mathrm{Cl}_{2}\right] \cdot 2 \mathrm{H}_{2} \mathrm{O}$ & $3417(\mathrm{br})$ & $3038(\mathrm{br})$ & 2978 & 2851,2912 & 1604 & $1574,1550,1522$ \\
\hline$\left[\mathrm{Cu}(\mathrm{L})_{2} \mathrm{Cl}_{2}\right] \cdot 2 \mathrm{H}_{2} \mathrm{O}$ & $3428($ br $)$ & $3043($ br $)$ & 2978 & 2851,2912 & 1604 & $1577,1552,1522$ \\
\hline
\end{tabular}

Abbreviations: $\mathrm{str}=$ stretching, $\mathrm{Ar}=$ aromatic, $\mathrm{Al}=$ Aliphatic, phen = phenanthroline, $\mathrm{br}=$ broad.

\section{Electronic spectra and magnetic measurements}

The electronic spectral data and magnetic moment of the compounds are given in Table 3 . In the electronic spectra of the ligand, the bands are observed in the $278-550 \mathrm{~nm}$ range. These bands are attributed to $\pi \rightarrow \pi^{*}$ and $\mathrm{n} \rightarrow \pi^{*}$ transitions [33-35]. 
The magnetic moment value for the Co(II) complex at $4.78 \mathrm{BM}$ reported here indicates a high spin octahedral configuration with three unpaired electrons [36, 37]. The electronic spectrum of the Co(II) complex gives two bands 410 and $500 \mathrm{~nm}$. These bands may be assigned to the transitions ${ }^{4} \mathrm{~T}_{1 \mathrm{~g}}(\mathrm{~F})\left(\mathrm{D}_{4 \mathrm{~h}} ;{ }^{4} \mathrm{E}_{\mathrm{g}}\right) \rightarrow{ }^{4} \mathrm{~T}_{1 \mathrm{~g}}(\mathrm{P})\left(\mathrm{D}_{4 \mathrm{~h}} ;{ }^{4} \mathrm{~A}_{2 \mathrm{~g}}\right)$ and ${ }^{4} \mathrm{~T}_{1 \mathrm{~g}}(\mathrm{~F})\left(\mathrm{D}_{4 \mathrm{~h}} ;{ }^{4} \mathrm{E}_{\mathrm{g}}\right) \rightarrow{ }^{4} \mathrm{~T}_{1 \mathrm{~g}}(\mathrm{P})\left(\mathrm{D}_{4 \mathrm{~h}} ;{ }^{4} \mathrm{E}_{\mathrm{g}}\right)$, respectively. The positions of these bands suggest a tetragonal environment around $\mathrm{Co}^{2+}$ ion [38]. The other bands of complex were not observed because they might be overlapped by the bands of L ligand.

The magnetic moment value (2.93 BM) for the Ni(II) complex corresponds to two unpaired electron [36, 39]. The absorption bands of this complex in the range 405-720 nm suggest a tetragonal environment around $\mathrm{Ni}^{2+}$ ion [38].

The magnetic moment value (1.95 $\mathrm{BM}$ ) for the $\mathrm{Cu}$ (II) complex corresponds to one unpaired electron $[36,40]$. The complex may be considered to have a tetragonal geometry. The electronic spectrum of the $\mathrm{Cu}$ (II) complex shows two bands at 415 and $720 \mathrm{~nm}$ assigned to ${ }^{2} \mathrm{E}_{\mathrm{g}}\left(\mathrm{D}_{4 \mathrm{~h}},{ }^{2} \mathrm{~B}_{1 \mathrm{~g}}\right)$ $\rightarrow{ }^{2} \mathrm{~T}_{2 \mathrm{~g}}\left(\mathrm{D}_{4 \mathrm{~h}} ;{ }^{2} \mathrm{~B}_{2 \mathrm{~g}},{ }^{2} \mathrm{E}_{\mathrm{g}}\right)$ and ${ }^{2} \mathrm{E}_{\mathrm{g}}\left(\mathrm{D}_{4 \mathrm{~h}},{ }^{2} \mathrm{~B}_{1 \mathrm{~g}}\right) \rightarrow{ }^{2} \mathrm{E}_{\mathrm{g}}\left(\mathrm{D}_{4 \mathrm{~h}} ;{ }^{2} \mathrm{~A}_{1 \mathrm{~g}}\right)$ transitions, respectively [38].

Table 3. Magnetic moment and electronic spectral data of the ligand and its complexes.

\begin{tabular}{|c|c|c|c|}
\hline Compound & $\begin{array}{c}\mu_{\text {eff }} \\
(\mathrm{BM})\end{array}$ & $\lambda(\mathrm{nm})$ & Assigned transitions \\
\hline $\mathrm{L}$ & - & $\begin{array}{l}278,291,309,320 \\
372,445,461,550\end{array}$ & $\pi \rightarrow \pi^{*}$ and $n \rightarrow \pi^{*}$ \\
\hline$\left[\mathrm{Co}(\mathrm{L})_{2} \mathrm{Cl}_{2}\right] \cdot \mathrm{H}_{2} \mathrm{O}$ & 4.78 & $\begin{array}{l}410 \\
500\end{array}$ & $\begin{array}{c}{ }^{4} \mathrm{~T}_{1 \mathrm{~g}}(\mathrm{~F})\left(\mathrm{D}_{4 \mathrm{~h}} ;{ }^{4} \mathrm{E}_{\mathrm{g}}\right) \rightarrow{ }^{4} \mathrm{~T}_{1 \mathrm{~g}}(\mathrm{P})\left(\mathrm{D}_{4 \mathrm{~h}} ;{ }^{4} \mathrm{~A}_{2 \mathrm{~g}}\right) \\
{ }^{4} \mathrm{~T}_{1 \mathrm{~g}}(\mathrm{~F})\left(\mathrm{D}_{4 \mathrm{~h}} ;{ }^{4} \mathrm{E}_{\mathrm{g}}\right) \rightarrow{ }^{4} \mathrm{~T}_{1 \mathrm{~g}}(\mathrm{P})\left(\mathrm{D}_{4 \mathrm{~h}} ;{ }^{4} \mathrm{E}_{\mathrm{g}}\right)\end{array}$ \\
\hline$\left[\mathrm{Ni}(\mathrm{L})_{2} \mathrm{Cl}_{2}\right] \cdot 2 \mathrm{H}_{2} \mathrm{O}$ & 2.93 & $\begin{array}{l}405 \\
418 \\
530 \\
561 \\
720\end{array}$ & $\begin{array}{c}{ }^{3} \mathrm{~A}_{2 \mathrm{~g}}\left(\mathrm{D}_{4 \mathrm{~h}} ;{ }^{3} \mathrm{~B}_{1 \mathrm{~g}}\right) \rightarrow{ }^{3} \mathrm{~T}_{1 \mathrm{~g}}(\mathrm{P})\left(\mathrm{D}_{4 \mathrm{~h}} ;{ }^{3} \mathrm{E}_{\mathrm{g}}\right) \\
{ }^{3} \mathrm{~A}_{2 \mathrm{~g}}\left(\mathrm{D}_{4 \mathrm{~h}} ;{ }^{3} \mathrm{~B}_{1 \mathrm{~g}}\right) \rightarrow{ }^{3} \mathrm{~T}_{1 \mathrm{~g}}(\mathrm{P})\left(\mathrm{D}_{4 \mathrm{~h}} ;{ }^{3} \mathrm{~A}_{2 \mathrm{~g}}\right) \\
{ }^{3} \mathrm{~A}_{2 \mathrm{~g}}\left(\mathrm{D}_{4 \mathrm{~h}},{ }^{3} \mathrm{~B}_{1 \mathrm{~g}}\right) \rightarrow{ }^{3} \mathrm{~T}_{1 \mathrm{~g}}(\mathrm{~F})\left(\mathrm{D}_{4 \mathrm{~h}} ;{ }^{3} \mathrm{E}_{\mathrm{g}}\right) \\
{ }^{3} \mathrm{~A}_{2 \mathrm{~g}}\left(\mathrm{D}_{4 \mathrm{~h}} ;{ }^{3} \mathrm{~B}_{1 \mathrm{~g}}\right) \rightarrow{ }^{3} \mathrm{~T}_{1 \mathrm{~g}}(\mathrm{~F})\left(\mathrm{D}_{4 \mathrm{~h}} ;{ }^{3} \mathrm{~A}_{2 \mathrm{~g}}\right) \\
{ }^{3} \mathrm{~A}_{2 \mathrm{~g}}\left(\mathrm{D}_{4 \mathrm{~h}} ;{ }^{3} \mathrm{~B}_{1 \mathrm{~g}}\right) \rightarrow{ }^{3} \mathrm{~T}_{2 \mathrm{~g}}(\mathrm{~F})\left(\mathrm{D}_{4 \mathrm{~h}},{ }^{3} \mathrm{E}_{\mathrm{g}},{ }^{3} \mathrm{~B}_{2 \mathrm{~g}}\right)\end{array}$ \\
\hline$\left[\mathrm{Cu}(\mathrm{L})_{2} \mathrm{Cl}_{2}\right] \cdot 2 \mathrm{H}_{2} \mathrm{O}$ & 1.95 & $\begin{array}{l}415 \\
720\end{array}$ & $\begin{array}{l}{ }^{2} \mathrm{E}_{\mathrm{g}}\left(\mathrm{D}_{4 \mathrm{~h}} ;{ }^{2} \mathrm{~B}_{1 \mathrm{~g}}\right) \rightarrow{ }^{2} \mathrm{~T}_{2 \mathrm{~g}}\left(\mathrm{D}_{4 \mathrm{~h}} ;{ }^{2} \mathrm{~B}_{2 \mathrm{~g}},{ }^{2} \mathrm{E}_{\mathrm{g}}\right) \\
{ }^{2} \mathrm{E}_{\mathrm{g}}\left(\mathrm{D}_{4 \mathrm{~h}} ;{ }^{2} \mathrm{~B}_{1 \mathrm{~g}}\right) \rightarrow{ }^{2} \mathrm{E}_{\mathrm{g}}\left(\mathrm{D}_{4 \mathrm{~h}} ;{ }^{2} \mathrm{~A}_{1 \mathrm{~g}}\right)\end{array}$ \\
\hline
\end{tabular}

Thermal analysis (TGA)

According to the thermogravimetric results all the complexes were stable up to $50{ }^{\circ} \mathrm{C}$. In the decomposition process of the complexes, the mass loss corresponded to one uncoordinated water molecule for $\left[\mathrm{Co}(\mathrm{L})_{2} \mathrm{Cl}_{2}\right] \cdot \mathrm{H}_{2} \mathrm{O}(2.50 \%$ experimental; $2.29 \%$ calculated $)$ and two uncoordinated water molecule for $\left[\mathrm{Ni}(\mathrm{L})_{2} \mathrm{Cl}_{2}\right] \cdot 2 \mathrm{H}_{2} \mathrm{O}$ and $\left[\mathrm{Cu}(\mathrm{L})_{2} \mathrm{Cl}_{2}\right] \cdot 2 \mathrm{H}_{2} \mathrm{O} \quad(4.58 \%$ experimental; $4.57 \%$ calculated and $4.16 \%$ experimental; $4.55 \%$ calculated) in the temperature range of $50-120^{\circ} \mathrm{C}$.

\section{Conductance measurements}

The molar conductivity values (Table 1) of all the complexes indicate that the complexes are non-electrolytes [41].

\section{Antibacterial activity}

The results concerning in vitro antibacterial activity of the ligand and its complexes together with the inhibition zone diameter (mm) and MIC values are presented in Tables 4 and 5 . 
Table 4. Antibacterial activity of the ligand and its complexes (inhibition zone diameter, mm).

\begin{tabular}{|c|c|c|c|c|c|c|}
\hline \multirow[b]{2}{*}{ Bacteria } & \multicolumn{6}{|c|}{ Antibacterial activity (IZD in $\mathrm{mm}$ ) } \\
\hline & $\mathrm{L}$ & {$\left[\mathrm{Co}(\mathrm{L})_{2} \mathrm{Cl}_{2}\right] \cdot \mathrm{H}_{2} \mathrm{O}$} & {$\left[\mathrm{Ni}(\mathrm{L})_{2} \mathrm{Cl}_{2}\right] \cdot 2 \mathrm{H}_{2} \mathrm{O}$} & {$\left[\mathrm{Cu}(\mathrm{L})_{2} \mathrm{Cl}_{2}\right] \cdot 2 \mathrm{H}_{2} \mathrm{O}$} & DMF & $\begin{array}{l}\text { Ampicillin } \\
\text { (AM10) }\end{array}$ \\
\hline $\begin{array}{l}\text { A. hydrophila } \\
\text { ATCC } 7966\end{array}$ & 19 & 11 & - & 16 & - & - \\
\hline $\begin{array}{l}\text { S. aureus } \\
\text { ATCC } 29213\end{array}$ & 21 & 14 & - & 15 & 7 & - \\
\hline $\begin{array}{l}\text { K. pneumoni } \\
\text { ATCC } 21541\end{array}$ & 18 & 17 & 17 & 17 & 14 & 16 \\
\hline $\begin{array}{l}P . \text { aeroginose } \\
\text { ATCC } 27853\end{array}$ & 14 & 7 & - & 8 & 11 & 18 \\
\hline $\begin{array}{l}\text { S. marcescens } \\
\text { ATCC } 21074\end{array}$ & 15 & 16 & 7 & 15 & 13 & 18 \\
\hline $\begin{array}{l}\text { E. aerogenes } \\
\text { ATCC } 5402\end{array}$ & 19 & 11 & - & 14 & 7 & 16 \\
\hline $\begin{array}{l}\text { B. subtilis } \\
\text { ATCC } 6633\end{array}$ & 20 & 15 & - & 17 & 7 & 8 \\
\hline $\begin{array}{l}\text { E. coli } \\
\text { ATCC } 25922\end{array}$ & 14 & 11 & 12 & 8 & 14 & 18 \\
\hline $\begin{array}{l}\text { E. faecalis } \\
\text { ATCC } 29212\end{array}$ & 22 & 16 & - & 20 & - & 7 \\
\hline
\end{tabular}

IZD = Inhibition zone diameter.

Table 5. Antibacterial activity of the ligand and its complexes (MIC, $\mu \mathrm{g} / \mathrm{mL}$ ).

\begin{tabular}{|c|c|c|c|c|c|}
\hline \multirow[b]{2}{*}{ Bacteria } & \multicolumn{5}{|c|}{$\mathrm{MIC}(\mu \mathrm{g} / \mathrm{mL})$} \\
\hline & $\mathrm{L}$ & {$\left[\mathrm{Co}(\mathrm{L})_{2} \mathrm{Cl}_{2}\right] \cdot \mathrm{H}_{2} \mathrm{O}$} & {$\left[\mathrm{Ni}(\mathrm{L})_{2} \mathrm{Cl}_{2}\right] \cdot 2 \mathrm{H}_{2} \mathrm{O}$} & {$\left[\mathrm{Cu}(\mathrm{L})_{2} \mathrm{Cl}_{2}\right] \cdot 2 \mathrm{H}_{2} \mathrm{O}$} & $\begin{array}{c}\text { Ampicillin } \\
\text { (AM10) }\end{array}$ \\
\hline $\begin{array}{l}\text { A. hydrophila } \\
\text { ATCC } 7966\end{array}$ & 250 & 125 & - & 250 & - \\
\hline $\begin{array}{l}\text { S. aureus } \\
\text { ATCC } 29213\end{array}$ & 250 & 250 & - & 125 & - \\
\hline $\begin{array}{l}\text { K. pneumoni } \\
\text { ATCC } 21541\end{array}$ & 250 & 250 & 62.5 & 125 & 3.91 \\
\hline $\begin{array}{l}\text { P. aeroginose } \\
\text { ATCC } 27853\end{array}$ & 250 & 31.25 & - & 31.25 & 7.81 \\
\hline $\begin{array}{l}\text { S. marcescens } \\
\text { ATCC } 21074\end{array}$ & 31.25 & 62.5 & 31.25 & 62.5 & 3.91 \\
\hline $\begin{array}{l}\text { E. aerogenes } \\
\text { ATCC } 5402\end{array}$ & 125 & 125 & - & 62.5 & 7.81 \\
\hline $\begin{array}{l}\text { B. subtilis } \\
\text { ATCC } 6633\end{array}$ & 125 & 125 & - & 125 & 15.63 \\
\hline $\begin{array}{l}\text { E. coli } \\
\text { ATCC } 25922\end{array}$ & 125 & 62.5 & 31.25 & 31.25 & 15.63 \\
\hline $\begin{array}{l}\text { E. faecalis } \\
\text { ATCC } 29212\end{array}$ & 62.5 & 250 & - & 250 & 7.81 \\
\hline
\end{tabular}

Interestingly, the ligand was found to exhibit significant antibacterial activity against all the bacteria tested. $\mathrm{Ni}(\mathrm{II})$ complex showed good antibacterial activity against $E$. coli and $K$. pneumoniae, respectively. $\mathrm{Cu}$ (II) complex also displayed good antibacterial activity against the tested bacteria. However, no effect was observed against $P$. aeruginos $a$ and $E$. Coli by both the 
2-p-Tolyl-1h-imidazo[4,5-f][1,10]phenanthroline and its $\mathrm{Co}(\mathrm{II}), \mathrm{Ni}(\mathrm{II})$ and $\mathrm{Cu}(\mathrm{II})$ complexes 219

ligand and the complexes. Further, antibacterial activity $\mathrm{Co}$ (II) complex was found to be significant effect against all bacteria. In contrast no effect was observed against $P$. aeruginosa. The very high antibacterial activities of the ligand, $\mathrm{Cu}$ (II) complex and the $\mathrm{Co}$ (II) complex could be further studied for the treatment of infections caused by any of the above organisms.

\section{CONCLUSION}

In this study, imidazole and phenanthroline containing 2-p-tolyl-1H-imidazo[4,5f] $[1,10]$ phenanthroline (L) and its complexes were synthesized and characterized. The analytical data, physical and spectroscopic studies suggest that the complexes were of the general formula $\left[\mathrm{M}(\mathrm{L})_{2} \mathrm{Cl}_{2}\right] \cdot \mathrm{nH}_{2} \mathrm{O}$ where $\mathrm{M}$ is $\mathrm{Co}(\mathrm{II}), \mathrm{Ni}(\mathrm{II})$ and $\mathrm{Cu}(\mathrm{II})$ and $\mathrm{n}$ corresponding to $\mathrm{M}$ is $1,2,2$, respectively. According to the IR data of the compounds, $\mathrm{L}$ is coordinated to the metal ions through nitrogen atoms of the $\mathrm{C}=\mathrm{N}$ (phenanthroline ring) groups. The biological activity test results showed that the ligand and its metal complexes have good antibacterial activity against the bacterial strains except for $\mathrm{Ni}$ (II) complex. We think that the ligand and the two metal complexes $(\mathrm{Cu}(\mathrm{II})$ and $\mathrm{Co}(\mathrm{II}))$ might be effective as antibacterial agents.

\section{ACKNOWLEDGEMENT}

We would like to thank Firat University, Elazig, Turkey, for the financial support.

\section{REFERENCES}

1. Chalk, S.J.; Tyson, J.F. Anal. Chem. 1994, 66, 660.

2. Samnani, P.B.; Bhattacharya, P.K.; Ganeshpure, P.A.; Koshy, V.J.; Satish, N. J. Mol. Catal. 1996, $110,89$.

3. Bachas, L.G.; Cullen, L.; Hutchins, R.S.; Scott, D.L. J. Chem. Soc., Dalton Trans. 1997, 9, 1571.

4. Fussa-Rydel, O.; Zhang, H.T.; Hump, J.T.; Leidner, C.R. Inorg. Chem. 1989, 28, 1533.

5. Pickup, P.G.; Osteryoung, R.A. Inorg. Chem. 1985, 24, 2707.

6. Sammes, P.G.; Yahioglu, G. Chem. Soc. Rev. 1994, 23, 327.

7. Calderazzo, F.; Pampaloni, G.; Passarelli, V. Inorg. Chim. Acta 2002, 330, 136.

8. Larsson, K.; Öhström, L. Inorg. Chim. Acta 2004, 357, 657.

9. Binnemans, K.; Lenaerts, P.; Driesen, K.; Görller-Walrand, C. J. Mater. Chem. 2004, 14, 191.

10. Lenaerts, P.; Storms, A.; Mullens, J.; D'Haen, J.; Görller-Walrand, C.; Binnemans, K.; Driesen, K. Chem. Mater. 2005, 17, 5194.

11. Williams, A.F.; Piguet, C.; Bernardinelli, G. Angew. Chem. Int. Ed. Engl. 1991, 30, 1490.

12. Hurley, D.J.; Tor, Y. J. Am. Chem. Soc. 2002, 124, 3749.

13. Felder, D.; Nierengarten, J.F.; Barigelletti, F.; Ventura, B.; Armaroli, N. J. Am. Chem. Soc. 2001, 123, 6291.

14. Connors, P.J.; Tzalis, J.D.; Dunnick, A. L.; Tor, Y. Inorg. Chem. 1998, 37, 1121.

15. Camren, H.; Chang, M.Y.; Zeng, L.; McGuire, M. E. Synth. Commun. 1996, 26, 1247.

16. Bolger, J.; Gourdon, A.; Ishow, E.; Launay, J. P. Inorg. Chem. 1996, 35, 2937.

17. Lehn, J.M.; Ziessel, R. Helv. Chim. Acta 1988, 71, 1511.

18. Coyle, B.; Kwanagh, K.; Mcxcann, M.; Devereux, M.; Geraghty, M. Biometals 2003, 16, 321.

19. Qizhuang, H.; Jing, Y.; Hui, M.; Hexing, L. Mater. Lett. 2006, 60, 317. 
20. Hiort, C.; Lincoln, P.; Norden, B. J. Am. Chem. Soc. 1993, 115, 3448.

21. Jorgensen, J.H.; Turnidge, J.D. Antibacterial Susceptibility Tests: Dilution and Disk Diffusion Methods in: Manual of Clinical Microbiology, Murray, P.R.; Baron, E.J.; Jorgensen, J.H.; Landry, M.L.; Pfaller, M.A. (Eds.), 9th ed., American Society for Microbiology: Washington, USA; 2007; pp. 72-115.

22. Jorgensen, J.H.; Ferraro, M.J. Clin. Infect. Dis. 2009, 49, 1749.

23. Reddy, V.; Patil, N.; Angadi, S.D. E. J. Chem. 2008, 5, 577.

24. Xu, H.; Zheng, K.C.; Chen, Y.; Li, Y.Z.; Lin, L.J.; Li, H.; Zhang, P.X.; Ji, L.N. Dalton Trans. 2003, 11, 2260.

25. Xu, H.; Liang, Y.; Zhang, P.; Du, F.; Zhou, B.-R.; Wu, J.; Liu, J.-H.; Liu, Z.-G.; Ji, L.-N. J. Biol. Inorg. Chem. 2005, 10, 529.

26. Swamy, S.J.; Pola, S. Spectrochim. Acta A 2008, 70, 929.

27. El-Sherif, A.A.; Shehata, M.R.; Shoukry, M.M.; Barakat, M.H. Spectrochim. Acta A 2012, $96,889$.

28. Masoud, M.S.; Ali, A.E.; Shaker, M.A.; Elasala, G.S. Spectrochim. Acta A 2012, 90, 93.

29. Erdik, E. Organik Kimyada Spektroskopik Yöntemler, Gazi Büro Kitabevi: Ankara, Turkey; 1993; pp.104-150.

30. Flakus, H.T.; Hachula, B.; Stolarczyk, A. Spectrochim. Acta A 2012, 85, 7.

31. Busch, D.H.; Bailar, J.C. J. Am. Chem. Soc. 1956, 78, 1137.

32. Mashaly, M.M.; El-Shafiy, H.F.; El-Maraghy, S.B.; Habib, H.A. Spectrochim. Acta A 2005, $61,1853$.

33. Bolger, J.; Gourdon, A.; Ishow, E.; Launay, J.-P. J. Chem. Soc., Chem. Commun. 1995, 17, 799.

34. Bolger, J.; Gourdon, A.; Ishow, E.; Launay, J.-P. Inorg. Chem. 1996, 35, 2937.

35. Kalanithi, M.; Rajarajan, M.; Tharmaraj, P.; Sheela, C.D. Spectrochim. Acta A 2012, 87, 155.

36. Huheey, J.E.; Keiter, E.A.; Keiter, R.L. Inorganic Chemistry, Principle of Structure and Reactivity, 4th ed., Harper Collins College Publisher: New York, USA; 1993; p 465.

37. Konstantinovic, S.S.; Radovanovic, B.C.; Krkljes, A. J. Therm. Anal. Calorim. 2007, 90, 525.

38. Lever, A.B.P. Inorganic Electronic Spectroscopy, 2nd ed., Elsevier: Amsterdam, Netherlands; 1984; p 863.

39. Patil, S.A.; Unki, S.N.; Badami, P.S. J. Therm. Anal. Calorim. 2013, 111, 1281.

40. Chandra, S.; Sharma, A.K. Spectrochim. Acta A 2009, 72, 851.

41. Geary, W.J. Coord. Chem. Rev. 1971, 7, 81. 